Itinéraires Itinéraires

Littérature, textes, cultures

\title{
The Hairdresser of Harare, Questioning Gender and Sexuality in a Zimbabwean Novel
}

Le Meilleur Coiffeur d'Harare : genre et sexualité dans un roman zimbabwéen

\section{Pierre Leroux}

\section{(2) OpenEdition}

Journals

\section{Electronic version}

URL: http://journals.openedition.org/itineraires/6058

DOI: 10.4000/itineraires.6058

ISSN: 2427-920X

\section{Publisher}

Pléiade

\section{Electronic reference}

Pierre Leroux, "The Hairdresser of Harare, Questioning Gender and Sexuality in a Zimbabwean Novel », Itinéraires [Online], 2019-1 | 2019, Online since 17 July 2019, connection on 01 August 2019. URL http://journals.openedition.org/itineraires/6058; DOI : 10.4000/itineraires.6058

This text was automatically generated on 1 August 2019

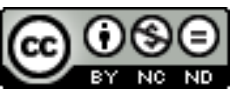

Itinéraires est mis à disposition selon les termes de la licence Creative Commons Attribution - Pas d'Utilisation Commerciale - Pas de Modification 4.0 International. 


\title{
The Hairdresser of Harare, Questioning Gender and Sexuality in a Zimbabwean Novel
}

\author{
Le Meilleur Coiffeur d'Harare : genre et sexualité dans un roman zimbabwéen
}

\author{
Pierre Leroux
}

1 Tendai Huchu's first novel, The Hairdresser of Harare was published in 2010 by Weaver Press. Although he was already living in Edinburgh at the time, the author made sure it was first released in Zimbabwe by a Zimbabwean publishing house. The story is set in Harare during the financial crisis that followed the land expropriations in the late nineties. The narrator, Vimbai, is a young single mother who claims to be the best hairdresser in the city. Her trade, and the fact that she describes herself as the "queen bee" (Hairdresser: 3) in the salon introduce her as a self-taught gender expert. She knows what is expected of women and provides her customers with the feminine image they long for. In her appreciation of her work, she even associates gender and race, since, according to her, the key to success is that the "client should leave the salon feeling like a white woman" (Hairdresser: 3). This curious assertion, reminiscent of Fanon, reveals a flaw behind the character's apparent confidence. If whiteness is a feeling, could womanhood be a performance rather than a fixed identity? Vimbai's convictions are challenged when Dumisani, a handsome talented young man, joins the team. She feels attracted to the newcomer, but it eventually transpires that he is gay. In the novel, this "gender trouble" (Butler 1990) is translated into what we should call a "genre trouble" as the author plays with the codes of "chick lit," this subgenre of the romance novel that originated with books such as Bridget Jones's Diary (Fielding [1996] 2016). ${ }^{1}$

2 As the author chose to be published in Zimbabwe, it is crucial to consider his target audience and the themes he presents in The Hairdresser of Harare. How does this gay character fit into the fictional universe? What are the strategies at play to present him as an everyman and not a tragic figure in a hostile environment? Far from the violent depictions of sexuality by a major Zimbabwean author like Dambudzo Marechera, Tendai Huchu's salon, while not hiding the precarious condition of a gay man forced to hide his 
sexual preferences, focuses first and foremost on his daily anecdotes and quibbles to convey a sense of normality.

In this paper, I intend to place The Hairdresser of Harare in its literary and social context. I argue that the use of a gay protagonist, while conveying a message of tolerance, also serves a more complex exploration of gender and genre. The subversion of "chick lit" and the use of conflicting narratives to depict homosexuality eventually contribute to bring about a striking depiction of a society in a crisis.

\section{Introducing a Gay Protagonist: Major Revolution and/ or Western Obsession}

Firstly, it is important to say a few words about the perception of homosexuality and its literary treatment in Zimbabwe. Some speeches and spectacular actions, as they occupy media space, may prove to be misleading and need to be put into context.

As Drew Shaw explains in his article "Queer Inclinations and Representations: Dambudzo Marechera and Zimbabwean Literature" (2005), 1995 was a turning point regarding the presence of homosexuality in Zimbabwean public space. The ban on GALZ (Gay and Lesbian of Zimbabwe Organization) at the Harare International Book Fair that year and Robert Mugabe's violent speeches prompted international indignation and opened up a national debate. Shaw sums up the new reality as follows:

Whereas few Zimbabweans had publicly discussed the subject previously, now it became unavoidable, thanks to a high-profile anti-gay campaign led by Robert Mugabe, who came to shape and symbolize a virulent new homophobic movement within pan-Africanism. Earlier Mugabe had declared homosexuality "anathema to African culture." Now he called on the public to purge Zimbabwean society of this "foreign vice." In response, the Church lent its wholehearted support to Mugabe's crusade, as did the media, which is mostly state-controlled. (Shaw 2005: 91)

With only a few references in Dambudzo Marechera's works and a short story on prison life by Stanley Nyamfukudza (1991), homosexuality does not seem to be a major theme in Zimbabwean literature prior to 1995. Although one cannot say it becomes more prevalent afterwards, it is important to note that major authors like Charles Mungoshi attempt to provide a more nuanced treatment of same-sex relationship. In his short story "Of Lovers and Wives" (Mungoshi 1997), he tells the story of Shamiso who finds out that her husband has been having an affair with his friend Peter for many years. This love story ends with Peter's suicide and it seems that, for Mungoshi, tragedy is the only way out for such a love triangle:

There could be no question about the rightness of certain situations, under certain circumstances. And when Chasi decided to leave town after Peter's funeral, preferring only to visit his wife occasionally during a weekend, Shamiso felt that that too had its own fitting rightness. (Mungoshi 1997: 111, my emphasis)

The repetition of the noun "rightness" points to a problematic sense of closure. ${ }^{2}$ Although the rest of the story is much more nuanced, this ending seems to confirm a certain vision of homosexuality. The following comment from pro-government newspaper, The Patriot, exemplifies, in my opinion, the dominant view on the matter. The story is presented as an "eye-opener to the younger generation who experiment with all sorts of ideologies and sensibilities that challenge the African way" (Tirivangani 2015). The author of this article considers that Charles Mungoshi is "making a statement" and he sums up, in a rather striking way, the intended meaning behind the story's tragic ending: "Homosexuality is 
an aberration that threatens the extinction of the future of the human race." This accusation is indeed recurrent, and I will comment on it when I examine Vimbai's reaction to the truth about Dumisani.

This cultural and literary context explains in part the attention Tendai Huchu's novel received. Here, not only is the gay protagonist a positive character, but he does not seem to be doomed and is eventually accepted for who he is by the female narrator. As a consequence, most articles studying The Hairdresser of Harare overtly embrace a sociological reading, instead of discussing its literary merits. For example, we find the following statement in Gibson Ncube's paper "Deconstructing the Closet: A Sociological Reading of Tendai Huchu's Novel, The Hairdresser of Harare": "I read The Hairdresser of Harare as a prism through which to consider the construction and functioning of the closet in contemporary Zimbabwe" (Ncube 2016: 12). Likewise, the assessment by Anna Chitando and Molly Manyonganise focuses on a social and moral standpoint:

We assert that Huchu has taken an important step to address the theme of homosexuality in Zimbabwe through creative writing. Although there are some difficult dimensions that come out in his approach, he must be acknowledged for his willingness to address a theme that remains "under the tongue" for many writers. (Chitondo and Mayonganise 2016: 567)

The novel is thus considered both as a sociological document and as a tool to influence public opinion.

7 When asked about the interest in this issue, Weaver Press publisher Irene Staunton offers an interesting shift in perspectives. Although she acknowledges that the novel "bravely addresses a very contentious issue" (Staunton 2017, email to the author), she insists on the fact that our view on the matter is largely distorted by media attention: "It seems to me that the attacks on this tiny minority, both verbal and physical, are always directed by some other force with another agenda." As a consequence, homophobia was not her main concern when she published the novel:

Thus, if the publication of the novel generated a certain anxiety on my part, this had more to do with the character of Minister M and her husband, as many would say they were easily identifiable. Besides, ironically, Dumisani, is thoroughly thrashed and goes into exile. The State would surely approve.

Political considerations weighed more heavily than the sociological issues that received attention outside Zimbabwe. Finally, she focuses on a more general view of society, insisting on the fact that The Haidresser of Harare cannot be limited to a pamphlet on homosexuality in Zimbabwe:

For me, the novel was so much more than the unfolding of the relationship between Vimbai and Dumisani, and its denouement. Huchu offered a light, tight but complex picture of life in Harare at a particular juncture, touching upon the farm invasions, race relations, the fundamentalist churches, patriarchal attitudes, sugar daddies, the newly rich, and much else besides. Much Zimbabwean writing reflects pain in many different manifestations. Huchu's great gift is the ability to explore difficult issues while being able to make his readers laugh.

For his part, Tendai Huchu insists on the gap in perceptions between Zimbabwean readers and Western readers: "There's a major difference. Zimbabwean readers enjoy the work more holistically and are able to read the nuance in the text. Westerners tend to view it as some kind of activist tract and less as an artistic piece" (Huchu 2017, email to the author).

As the novel was published in a very particular context and was mainly commented on from a sociological point of view, it seemed important to offer a new perspective on these 
conflicting standpoints. It is also essential to go further in order to question the relationship between gender and genre in the novel.

\section{Gender and Genre, Introducing "Subversive Repetition"}

Dumisani, who is both very attractive and out of reach for the female characters, appears to be in-between worlds, and this elusiveness has an impact on Vimbai's narrative. The references to popular genres such as the fairy-tale or the romance novel act as structures within which the narrator attempts to inscribe Dumisani's behaviour. Genre and gender both play on the reader's normative expectations to present them with a new perspective. In that regard, Tendai Huchu's strategy is quite close to what Judith Butler calls "subversive repetition":

The critical task is, rather, to locate strategies of subversive repetition enabled by those constructions, to affirm the local possibilities of intervention through participating in precisely those practices of repetitions that constitute identity and, therefore, present the immanent possibility of contesting them. (Butler 1990: 147)

Like the classical comedy which originates from a fertility myth, romance novels and fairy-tales end up in marriage more often than not. Therefore, as both genres appear to consolidate heterosexual normativity, it seems rather efficient to use them as a means of subversion. Tendai Huchu, although he does not claim such a use of literary techniques, shows a real interest in what has been called "paralittérature" (Bleton 1999). He explains how these genres are useful to explore other matters:

I think genre is a very important item in the writer's toolkit. By this I mean certain preexisting narratological conventions are very useful in terms of signaling certain things and/or allowing certain kinds of stories to be told. If you think of stories as simulations of real life then mystery is very good for doing plot-heavy work and sci-fi works well in terms of exploring unusual ideas and mastering worldbuilding craft. Literary fiction with its demands on characterization adds another dimension. None of these things are specific or exclusive to those genres, but one feels like they're working different muscles when immersed in each genre, and this practice can only make for better craftsmanship down the road. (Huchu 2017, email to the author, my emphasis)

Here, the author describes his work in terms of craftsmanship and he significantly avoids all references to the sociological dimension of his writing. It is important to note that, unlike other writers, Tendai Huchu does not commit to one genre and seems to make a distinction between his short stories and his novels. Whereas the former are akin to exercises in style, the latter are more elaborate and combine the various skills listed above. Huchu's first two novels never narrowly fit into one particular genre but they draw from various sources to offer a more complex treatment of the story.

Since he published The Hairdresser of Harare, Tendai Huchu has been experimenting with various popular literary genres. He has written a mystery story for Ellery Queen's Mystery Magazine, ${ }^{3}$ a handful of science-fiction short-stories ${ }^{4}$ and his last novel, The Maestro, the Magistrate and the Mathematician (Huchu 2014), contains some features of a spy novel. This eclectic production reflects the new trends of African literatures. ${ }^{5}$

11 To illustrate this briefly before returning to The Hairdresser of Harare, I would like to present one very interesting example of how science-fiction enables a questioning of gender and empowerment in Zimbabwe. In "The Sale," the protagonist, Mr Munyuki, has to take a daily suppository of a drug that represses his need to rebel while causing his breasts to grow: "He fiddled behind his back to remove his 36A bra. He moved his hands 
to feel his boobs, a known side effect of the daily doses of NeustrogenAlpha." (Huchu 2012: 38) Testosterone is presented as the source of all rebellion and is therefore strictly controlled by the authorities: "all natives were required to maintain low testosterone levels in public unless otherwise authorised as in the role of native policeman or bouncer" (Huchu 2012: 36). This restriction of manhood is here implicitly associated with the loss of economic power and even cultural identity. Although he regains agency by committing suicide, the character's loss of power is symbolized by his hormone chemistry.

This tension between estrogen and testosterone is absent in The Hairdresser of Harare, where Tendai Huchu goes to great lengths to introduce nuances into traditional gender representations. Vimbai is an independent single mother and Dumisani appears as a gay character who is not effeminate. Although he claims he did not intend to emulate the romance novel, Tendai Huchu acknowledges the "breezy feel to the narrative" (Huchu 2017). As for the other genres, he finds in "chick lit" some traits that allow him to tell a better story: "While some may sneer at it (largely because it is a female dominated area) I feel, even as an outsider, romance captures the drama of intimate, interpersonal relationships better than anything else" (Huchu 2017). In fact, Vimbai, a young independent woman looking for love, has a lot in common with the characters of such books:

In their novels, the authors follow a well-established storyline that focuses on the rather dramatic life of a white female protagonist and her obsession with body weight and diets, good looks and beauty routines, frequent shopping sprees and infinite chats with her best girlfriends. The reader encounters an allegedly typical modern-day woman, who, despite her financial independence and an oftentimes satisfying career, is primarily occupied with her feminine appearance and the impression her appearance has on the opposite sex. (Eichmanns Maier 2017: 100)

Vimbai owns her own house and she's satisfied with her career, but Tendai Huchu also introduces significant differences. For instance, she is black and the "shopping sprees," due to the Zimbabwean financial crisis, are replaced by endless queuing. While Helen Fielding's Bridget Jones writes in her New Year's resolution that she must not "spend more than earn" (Fielding 2016: 2), Vimbai explains that she must save electricity because she is "two months behind with payment" (Hairdresser: 11). The "breezy feel" mentioned above mostly come from the rendition of small talk and gossip in the salon, such as this graphic trashing of competition:

"Everyone who goes there comes back. I hear horror stories about people's hair snapping off." It was an exaggeration but destroying a competitor's reputation was all part of the game. Easy Touch, in turn, spread a rumour that we were wenches who wanted to steal our customer's husbands. (Hairdresser: 5)

The narrator is quick to respond to the other characters, but she also uses her privileged standpoint to draw some satirical portraits: "we were all beautiful except for Agnes who shared her mother's toadyish shape. Neither mother nor daughter had necks. Shame" ( Hairdresser: 5). The choice of adjective ("toadyish") and the final interjection ("Shame") both point to a narrative that mimics conversation.

13 Vimbai tells her story as if it was a romance novel but the reader soon understands that an essential feature of the genre won't be possible: if Dumisani is gay, then they cannot get married and live happily ever after. Part of the interest of The Hairdresser of Harare thus lies in the fact that the expected love story cannot happen. This shift in perspective allows Tendai Huchu to use the elements of "chick lit" that interest him while playing 
with expectations to reveal the real issues at stake. His characters-Dumisani more so than the others-are designed to defy stereotypes.

Dumi, without being too specific about the nature of their relationship, introduces Vimbai to his wealthy family. They instantly adopt her and even buy her a salon in Borrowdale, an upmarket part of the city. As she later begins to have doubts about Dumi's intentions, the young woman herself then compares her love-story to a fairy-tale: ${ }^{6}$

I'd loved Dumi even when I had thought he was as ordinary as myself, but looking back it became blurry as to whether it would have gone this far if I had not found out about his privileged background. Sure, it has kind of added to the fairy-tale... but I

wasn't certain that I wanted to go down this route. (Hairdresser: 158, my emphasis)

The "route" Vimbai is talking about leads to one of the criticisms often aimed at romance novels, which is that they publicize an image of women as depending on the wealth and strength of men. As in fairy-tales, the princess must be saved by a prince who is both handsome and rich.

Like the "chicana chick lit" in the United States and its Turkish counterpart in Germany (Eichmanns Maier 2017), Tendai Huchu uses the characteristics of this very popular genre to portray a modern Zimbabwean woman while acknowledging that she does not come from the same privileged background as a European Bridget Jones. Yet, as far as Dumisani is concerned, it is important to note that, although the reader quickly understands that he is gay, the narrator, Vimbai, keeps beating about the bush. It seems that this false mystery is essential to understand Huchu's treatment of homosexuality in the novel.

\section{What is Wrong with "Mr. Right,"7 Introducing Conflicting Narratives}

16 It seems quite strange that the narrator, while indirectly giving clues to Dumisani's homosexuality, never seems to suspect the truth. In the final part of this paper, I will argue that the representations of gender and sexuality are put into perspective through conflicting narratives and voices staged within the novel. Vimbai only unveils the truth when Dumisani, through his diary, himself becomes a narrator.

The claim that homosexuality is in some way "un-African" has been widely discussed and when Dumisani attempts to conceal his sexual orientation, he is in fact attempting to comply with this dominant point of view. Nevertheless, he never fully surrenders to this hegemony and many details help alert the reader to the fact that he does not fit in. To understand this and to accept him as he is, Vimbai has to completely transform her mindset. The invisibility of Dumi's sexual preferences seems to arise from the tension between the socially accepted violence of men and the demonization of homosexuality.

In this perspective, the very first sentences of the novel set the tone for the treatment of Dumi's homosexuality in The Hairdresser of Harare: "I knew there was something not quite right about Dumi the very first time I ever laid eyes on him. The problem was, I just couldn't tell what it was. Thank god for that" (Hairdresser: 1). Commenting on those opening lines, Chitondo and Mayonganise feel they have a negative effect since "they buttress the incorrect view that homosexuals are "abnormal"' (Chitondo and Mayonganise 2016: 570). Although this ideological standpoint is understandable, it seems important to underline that it is the narrator, Vimbai, and not the author who is using that phrase. 
This first hint of Dumisani's difference is followed by many others. When he first enters the salon, for example, his career choice sets him apart: "These were difficult times and jobs were scarce but I'd never thought that men might try to get a woman's job" ( Hairdresser: 7). Most of the time, Vimbai sees him as a paradox, since he appears to be the perfect man but seems to possess none of the usual faults of his kind: "A guy like him being single was next to impossible. He should have had a girlfriend" (82-83).

The young man embodies all the qualities usually associated with masculinity. Even though she is initially in competition with him, Vimbai, as well as the patrons of the salon, insist on how special Dumi is: "To find a man who can groom himself in Zimbabwe is next to impossible, but what are the odds of finding one who can groom you as well?" (38). The conclusion of this conversation exemplifies the treatment of gender we find in the novel: "A man so comfortable with his own masculinity was hard to find" (Hairdresser: 38). The disjunction of sex ("man") and gender ("masculinity") troubles fixed categories and reveals that these identities are social constructs. ${ }^{8}$

The traditional men, in contrast, show very predictable behavior. Random men Vimbai meets in the streets seem to follow identical patterns while interacting with her:

He looked like a typical nice guy. It's a pity he didn't know that I hadn't been in a relationship for six years and had no intentions of changing that. Men didn't appeal to me anymore. They couldn't be trusted.

"You think you're special, but you're not even beautiful" he finally volunteered. Getting abused was nothing new. "You'll die without a man."

A kombi ${ }^{9}$ came by and I jumped in, glad to escape. Men don't take rejection so well. It's like they're raised expecting that they can have whatever they want. ( Hairdresser: 24)

The interesting part lies in the fact that this aggressive behavior comes from a "typical nice guy." The standards for manhood are linked to verbal violence and domination whereas Dumisani shows respect and courage when confronted with a dangerous situation. For instance, he takes the risk of being beaten up by war veterans to protect Trina, a white woman who used to be a farmer and who acts as a supplier for the salon.

As she sees Dumi is special, Vimbai-unlike most readers-fails to understand that he is gay until, out of jealousy, she searches his room and stumbles upon his diary. This blindness is not specific to Huchu's novel and it can also be found in Mungoshi's short story. Shami has lived for years with her husband before finding out the truth. It seems as if she did not see because she could not conceive of this relationship: "she [...] realized with shocking clarity that the two men hadn't hidden anything from her, but that she had been blind to what was going on right under her very nose" (Mungoshi 1997: 106).

Dumisani clearly does not fit in the caricatural representations of a gay character. This dawns on Vimbai as she is finally confronted with the truth:

DUMI IS A HOMOSEXUAL - Ngochani. If it wasn't written in his hand and before my eyes, I would have denied it. I could not have foreseen this. He spoke like a normal man, wore clothes like a normal man and even walked like a normal man. Everything about him was masculine. Didn't homosexuals walk about with handbags and speak with squeaky voices? (Hairdresser: 166)

The use of capital letters emphasizes the shock she experienced, ${ }^{10}$ but the use of the Shona word "Ngochani" discreetly reminds us that this reality-homosexuality-is not absent in African cultures, since there is a word for it. ${ }^{11}$

Vimbai cannot see the truth because she is influenced by various narratives which tend to build a phantasmatic portrait of homosexuals. For example, when she takes Dumisani to

Itinéraires, 2019-1 | 2019 
church with her, pastor Roger Mvumba delivers a sermon on morality that relies on the Bible to prove that homosexuals should be rejected:

Timothy 3:1-9 teaches that "Men will be lovers of themselves in the last days." You must be on the lookout for homosexuals and sexual deviants. Perverts shall burn. How can a man and another man sleep together? God made Adam and Eve not Adam and Steve. Can a woman and a woman make a baby? (Hairdresser: 72)

Overlooking the possibility that the quote could point to selfishness, the pastor unfurls his discourse of hatred. As Vimbai thinks this is "a powerful sermon filled with the power of the Holy Spirit," Dumisani asks to leave the church. Here, homosexuals are condemned from a moral and religious standpoint. The reference to the "last days" places this sexual preference in an apocalyptic background and it seems, then, that the acceptance of homosexuality is associated with the collapse of society. This caricature is not specific to Zimbabwe or even Africa, but it takes on a particular meaning in the context of very serious social and economic difficulties. In this narrative, homosexuals are presented as a cause, or at least a symptom of the crisis.

The sermon leaves no room for contradiction, it is presented as a statement and the audience, like Vimbai, may only approve and cheer. When she later tries to understand Dumisani, the young woman goes to her brother, Fungai, who presides over a philosophy club. This time, the lesson takes the form of a dialogue as Socrates is invoked as an example:

"That can only lead to the conclusion that man and woman may not be as distinct as they seem," said one called Armstrong.

"Correct. When we use our brains, we can see that between these two genders there are a myriad possibilities; the leap from male to female is not as straightforward as our senses tell us. Therefore when you look at what you think is a man and what you think is a woman, you often fail to recognize or acknowledge all the other ambiguous possibilities."

(At this point one of them stood up and left.) (Hairdresser: 177)

The various interventions and the use of logical operators such as "Therefore" point to a rational approach to the question. It is also important to note that the character appeals to "our brains" whereas pastor Mvumba relies on emotions and puns such as "Adam and Steve." Although most of the listeners are not ready to hear this and leave, the staging of a rational debate provides Vimbai with an alternative narrative on homosexuality.

Both the moral condemnation and the philosophical rehabilitation present the homosexual as a subject matter and not an actual person. Dumisani's diary then indirectly allows the young man to speak for himself. The whole of chapter thirty-four is dedicated to the transcription of some of the most meaningful entries. As in mystery novels, this secret diary is meant to shed a new light on the story. Episodes like the wedding of Dumi's brother Patrick or Dumi's promotion in the salon are narrated from a different perspective. In this text, emphasis is put on the young man's struggle to be accepted as he is and his reluctant decision to hide his preferences: "Need to tell Vimbai everything. Is it too soon? Seems like a really nice person. Don't know who to trust any more... It's way too risky. [...] Can't afford to mess this up. Shouldn't have to live my life in the shadows like this" (Hairdresser: 165, author's italics). Ironically, these short, elliptic sentences are much closer to Helen Fielding's style than the rest of the novel. Bridget Jones, like Dumisani, uses her diary to express her fears and longings: "Nightmare day in office. Watched the door for Daniel all morning: nothing" (Fielding 2016: 25). Tendai Huchu thus aims to create a sense of intimacy with his character. 
Vimbai's discovery leads to a series of events that will culminate in Dumisani being left for dead and forced to leave the country. As his lover happens to be the husband of a government minister, the young man is beaten up by "war vets" and his only escape is to go into exile. Although we can only agree with Chitando and Mayonganise who insist on the "persistence of the theme of violence in Huchu's work" (2016: 570), it is important to stress that, unlike in Mungoshi's story, the gay protagonist does not die and Vimbai's view on the subject undergoes a spectacular change. The last paragraph of the novel echoes its opening lines: "In a way I will always love Dumi. He restored my faith that there are still some good men out there" (Hairdresser: 189). The "something not quite right" from the first sentence of the novel has disappeared to establish Dumi as an example for other men.

\section{Conclusion}

The critical reception of The Hairdresser of Harare and its place in the Zimbabwean literary landscape are crucial to understand the treatment of homosexuality in the novel. Political propaganda tends to distort our view of the issue and explains in part the gap in perception between Western and Zimbabwean readers. It seems nonetheless that, when compared to other stories, such as Mungoshi's "Of Lovers and Wives," Huchu's novel adds a new complexity to the depiction of gay characters in Zimbabwe.

As the "chick lit" novels question the heritage of feminism, The Hairdresser of Harare plays with the reader's expectations to question gender and sexuality in modern day Zimbabwe. Vimbai's dilemma at the beginning of the novel is quite close to Bridget Jones's ironic statement in Helen Fielding's book:

This confusion, I guess, is the price I must pay for becoming a modern woman instead of following the course of nature intended by marrying Abnor Rimmington off the Northampton bus when I was eighteen. (Fielding 2016: 103)

The "confusion" stems from the tension between two conflicting views of what it means to be a woman. On the one hand, she must be financially independent and have a career. On the other hand, she still dreams of a handsome and preferably rich prince charming. In this perspective, the "course of nature" may be interpreted as the heteronormative framework that is examined in Tendai Huchu's novel.

30 I have described Dumisani as invisible because he hides his sexual preferences and because Vimbai does not realize he is gay until she is confronted with a written confession. Since the debate on homosexuality is developed through various discourses and dialogues, it may be more accurate to say that he is inaudible. Whereas the pastor's sermon and Fungai's philosophical approach deal with an abstraction, the diary allows the reader to enter the young man's intimacy. As he must go into exile, the gay protagonist is silenced once more and the main narrator, Vimbai, is left to interpret his story. If the novel is not, as Tendai Huchu suggested, an "activist tract" (Huchu 2017), the character of Dumisani does work as a catalyst to reveal hidden tensions and explore the contradictions of a society in crisis. 


\section{BIBLIOGRAPHY}

Bleton, Paul, 1999, Ça se lit comme un roman policier : comprendre la lecture sérielle, Québec, Éditions Nota Bene.

Butler, Judith, 1990, Gender Trouble: Feminism and the Subversion of Identity, New York, Routledge.

Chitando, Anna and Manyonganise, Molly, 2016, "Saying the Unsaid: Probing Homosexuality in The Hairdresser of Harare," Journal of Homosexuality, Vol. 63, No. 4, pp. 559-74.

De Meyer, Bernard, Halen, Pierre et Mbondobari, Sylvère, 2013, Le Polar africain, Metz, Université de Lorraine, Centre de recherche "Écritures".

Eichmanns Maier, Gabriele, 2017, "Shoes, Shopping, and the Search for Mr. Right: Investigating the Trivial in Recent Turkish-German Chick Lit," Monatshefte, No. 109, p. 100-123.

Epprecht, Marc, 2004, Hungochani, The Story of a Dissident Sexuality in Southern Africa, Montreal, McGill-Queen's University Press.

Fielding, Helen, [1996] 2016, Bridget Jones's Diary, London, Picador Classic, electronic edition.

Huchu, Tendai, 2010, The Hairdresser of Harare, [Harare, Weaver Press] Auckland Park, Jacana.

Huchu, Tendai, 2012, "The Sale," in Ivor W. Hartmann (ed.), AfroSF: Science Fiction by African Writers, Milton Keynes, Story Time Publishing.

Huchu, Tendai, 2014, The Maestro, the Magistrate and the Mathematician, Bulawayo, AmaBooks.

Huchu, Tendai, 2014, "Hostbods," Omenana, 30 November 2014, [Online], https:// omenana.com/2014/11/30/hostbods/, accessed 16 July 2019.

Huchu, Tendai, 2015, “The Best Man,” Ellery Queen Mystery Magazine, No. 887.

Huchu, Tendai, 2016, “The Marriage Plot," Omenana, 25 March 2016, [Online], https:// omenana.com/2016/03/25/the-marriage-plot/, accessed 16 July 2019.

Huchu, Tendai, 2017, Email to the author, received 27 June 2017.

Isbister, Georgina, 2009, “Chick Lit: A Postfeminist Fairy Tale,” Working Papers On The Web, [Online], https://extra.shu.ac.uk/wpw/chicklit/isbister.html, accessed 16 July 2019.

Mungoshi, Charles, 1997, "Of Lovers and Wives," in C. Mungoshi, Walking Still, Harare, Baobab Books, pp. 105-112.

Ncube, Gibson, 2013, “The Festering Finger?," Reimagining Minority Sexuality in Tendai Huchu's The Hairdresser of Harare and Abdellah Taïa's Une Mélancolie Arabe," Current Writing: Text and Reception in Southern Africa, Vol. 25, No. 1, p. 66-75.

Ncube, Gibson, 2016, "Deconstructing the Closet: A Sociological Reading of Tendai Huchu's Novel, The Hairdresser of Harare," South African Review of Sociology, Vol. 47, No. 3, pp. 8-24.

Nyamfukudza, Stanley, 1991, "Posters on the Wall," in If God was a Woman, Harare, College Press. Nyéla, Désiré, 2017, La Filière noire, Dynamiques du polar “made in Africa," Paris, Honoré Champion. Raftopoulos, Brian and Mlambo, Alois S. (eds.), 2009, Becoming Zimbabwe: A History from the Precolonial Period to 2008, Avondale, Weaver Press. 
Shaw, Drew, 2005, "Queer Inclinations and Representations: Dambudzo Marechera and Zimbabwean Literature," Matatu, Vol. 29-30, No. 1, p. 89-112.

DOI: $10.1163 / 18757421-029030007$

Staunton, Irene, 2017, Email to the author, received 22 June 2017.

Smyczynska, Katarzyna, 2007, The World According to Bridget Jones, Frankfurt, Peter Lang.

Tirivangani, Augustine (Dr), “An Africa-centered Critique of Walking Still... a Close Analysis of 'Of Lovers and Wives'," The Patriot, 14 May 2015, [Online], https://www.thepatriot.co.zw/old_posts/ an-africa-centred-critique-of-walking-still-a-close-analysis-of-of-lovers-and-wives/, accessed 16 July 2019.

\section{NOTES}

1. On that topic, see The World According to Bridget Jones: "[Chicklit's] popularity was boosted by the publication of the best-selling British novel Bridget Jones's Diary by Helen Fielding, which re-inscribes some plots from Austen's novels into a contemporary context and seemingly has analogous ironic distance toward prevalent social norms. Because of chicklit's structural affinities with numerous pulp romances, the convention has also been designated as an updated version of Mills and Boone romantic formula, though targeted are a younger readership" (Smyczynska 2007: 7).

2. On this affirmation of heteronormativity, Drew Saw comments: "I do not dispute the possible occurrence of such situations and tragedies in real life. I do, however, question Mungoshi's use of the device of closure here to seal off a heteronormative moral orderthe attempt to declare it ultimately unassailable" (Shaw 2005: 100).

3. The short story "The Best Man" (Huchu 2015) focuses on the enquiry of female detective Munatsi who tries to solve the murder of a young boy in Harare.

4. The complexity of The Hairdresser of Harare is reflected in the variety of those texts. On the one hand, in "Hostbods" (Huchu 2014), the author imagines a new kind of slavery as young people rent out their bodies to older or impotent clients. "The Marriage Plot" (Huchu 2016) on the other hand, explores a time paradox in a humorous story about a time traveler who cannot make up his mind about marriage.

5. Although South African crime stories have had a great reputation since the eighties, the development of popular genres is quite recent in francophone and anglophone African literatures. Science fiction novels like Lagoon by Nnedi Okorafor (Nigeria, 2014) or crime stories like Tail of the Blue Bird by Nii Ayi Kwei Parkes (Ghana, 2009) prove that those genres have the potential to question the present situation in modern African countries. For francophone thrillers, see also La Filière noire, Dynamiques du polar "Made in Africa" (Nyéla 2017) and Le Polar africain (De Meyer, Halen et Mbondobari 2013). Romance novels are also well represented in the Ankara Press collection, with titles like Love's Persuasion (Awonubi, 2016).

6. On the connection between "chick lit" and fairy tale, see Georgina C. Isbsiter's article: “Chick Lit, a Postfeminist Fairy Tale?" (2013).

7. Mr Right is the name often given to the modern equivalent of a prince charming. We borrow this expression from the title of Eichmanns Maier's article on Turkish "Chick Lit": "Shoes, Shopping and the Search for Mr. Right" (2017). 
8. Examining the theories of Monique Wittig, Judith Butler considers this distinction as an important tool for subversion: "If gender is not tied to sex, either causally or expressively, then gender is a kind of action that can potentially proliferate beyond the binary limits imposed by the apparent binary of sex" (Butler 1990: 112).

9. Name given to collective taxis in Zimbabwe.

10. See also Ncube's analysis of this excerpt: "The use of capitalisation in the above passage serves not just as a typographical sign but more importantly as a psychological marker that immediately captures the attention of the reader. The subsequent use of the Shona word 'ngochani' (homosexual) in italics functions in the same manner as the preceding capitalisations" (Ncube 2013: 70).

11. On this topic, see Marc Epprecht's book Hungochani, the Story of a Dissident Sexuality in Southern Africa (2004).

\section{ABSTRACTS}

As gay characters have been rather rare in Zimbabwean literature, Tendai Huchu's first novel, The Hairdresser of Harare attracted a lot of attention when it was published in 2010. The story of Vimbai, a single mother who dreams of owning her own salon, and Dumisani, her friend who tries to hide his sexual preferences, thus works as a catalyst to explore different aspects of a society in crisis. For those reasons, the author has been both praised and criticized. In this article, I argue that, in the novel, the depiction of homosexuality is closely related to the exploration of popular literary genres such as the romance novel. The subversion of "chick lit," for instance, allows Tendai Huchu to question fixed gender categories and sexuality. The author reveals the violence Dumisani undergoes by using several conflicting narratives that try to depict and analyze homosexuality.

Les personnages gays demeurent rares dans la littérature zimbabwéenne et le premier roman de Tendai Huchu, The Hairdresser of Harare, a attiré l'attention des commentateurs dès sa sortie en 2010. En effet, l'histoire de Vimbai, une mère célibataire qui rêve de posséder son propre salon de coiffure, et de son ami Dumisani, qui tente de masquer ses préférences sexuelles permet de révéler divers aspects d'une société en crise. Pour ces raisons, l'auteur a été aussi bien loué que critiqué. Dans cet article, je pars de l'idée que la représentation de l'homosexualité et des questions de genre (gender) est indissociable au sein de ce roman du travail sur les genres littéraires populaires, au premier rang desquels se trouve le roman sentimental. Dans cette perspective, l'usage subversif de la «chick lit» permet à Tendai Huchu de questionner les catégories figées du genre (gender) et les représentations de la sexualité. C'est en déléguant à plusieurs voix narratives - parmi lesquelles l'intéressé lui-même - le débat sur l'homosexualité, que l'auteur parvient à rendre compte de la violence dont est victime Dumisani. 
INDEX

Mots-clés: Zimbabwe, homosexualité, études de genre, roman sentimental, genre littéraire, Mugabe (Robert), Huchu (Tendai)

Keywords: Zimbabwe, homosexuality, gender studies, genre, romance novel, Mugabe (Robert), Huchu (Tendai)

\section{AUTHOR}

PIERRE LEROUX

Université Paris 3 Sorbonne Nouvelle, Sorbonne Paris Cité 